\title{
The Role of Islam toward the Patriarchal Culture in Malay People
}

\author{
Randi Salim $^{1, *}$, Muhamad Fadhil Nurdin ${ }^{2}$, Bintarsih Sekarningrum $^{2}$, Prengki $^{3}$ \\ ${ }^{1}$ Master Student of Sociology, Faculty of Social and Political Science, Padjadjaran University, Indonesia \\ ${ }^{2}$ Senior Lecturer in Department of Sociology, Padjadjaran University, Bandung, Indonesia \\ ${ }^{4}$ Student of Psychology, Faculty of Psychology, Padjadjaran University, Taman Siswa Yogyakarta, Indonesia
}

Copyright $(\mathrm{C} 2017$ by authors, all rights reserved. Authors agree that this article remains permanently open access under the terms of the Creative Commons Attribution License 4.0 International License

\begin{abstract}
The culture of patriarchy is an old-dated custom which is identic to the people of Indonesia, especially the Malay people. The influence of Islam toward the patriarchal culture is quite significant whereas Islam believes in male's leadership upon the female. Islam is one of several old religions in Indonesia, no wonder, several systems were made are inspired of Islamic values. Patriarchal culture is deeply rooted in the soul of Indonesian people, not only the Malay people who believe in such culture but also the Javanese people do. The focus of the paper is examining how Islam influences toward the patriarchal culture of Malay people. The focus of the patriarchal culture that is obtained is influenced by Islamic religion, as stated in the quran surat An-Nisa ' [4]: 34 which States the man was the leader of the women. This study employs qualitative analysis method with data presentation in descriptive way of library study.
\end{abstract}

Keywords Role, Islam, Culture, Patriarchal, Malay

\section{Introduction}

Islam is one of official religions in Indonesia and Indonesia has the most Muslim in the world. Islam went in to Indonesia in the $13^{\text {th }}$ century. Islam has important role in the making of the people's socio-cultural system in Indonesia, especially in the sense of leadership. Islamic leadership put male in important positions, such as in leading a family, a workplace, as a nation.

To quote the words of Jorge Luis Borges (1973) that the world in which we live is a parody of a silly mistake. Mirror-mirror of fatherhood (fatherhood), because it has been multiplying and justify the ridiculous parody is the disgusting unclean. Resistance in silence is a virtue most of all. For those who choose to break away from the Prophet, had only two ways to get there: the self-indulgence of desires or curb with orgi, dutifully on the meat or be refusing it (Turner, 2003). In the citations that Jorge Borges says the world is a mysterious and often irrational. Then in this case the Borgesian concluded two principal solutions to problem namely, the question on teodesi, according to Kolakowski (1982) that the omnipotence of God before the crime is most major aspects of the religion (Turner, 2003). As a leader in a family, a male directs the way the family is going to be and makes decision on every action. A male has role in conducting a family leadership in Islam. It is a must for a male Muslim to be a leader in a family or as a caliph. According to Durkheim (1961) that the religious set of beliefs and practices of the prate associated with social bonding that creates the sacred between individuals in society (Turner, 2003). If it is related to leadership, there will be such Al-Khilafah or a governance of Islamic system as brought and administered by Prophet Muhammad SAW which was later administered by the Khulafaur Rasyidin such as Abu Bakar, Umar bin Khattab, Usman bin Affan, dan Ali bin Abu Talib (Rasjid, 2007). Allah Almighty says:

"And [mention, O Muhammad], when your Lord said to the angels, 'Indeed, I will make upon the earth a successive authority." (Al-Baqarah [2]: $30)$.

As the caliph on earth, human has high level compared to the other creature made by Allah. Male and female has their own role in social life. As the human who populated the planet earth, human has to make harmony of environment and nature. The role of female is not less important to family. Prophet Muhammad SAW said that:

"Female is the leader of her husband's housewifery and her children, and she'll be asked about them." (Bukhari and Muslim)

Based on that hadith, female has also important roles in a family, as a mother who keeps the family in harmony as described in Islamic sharia. The Malay people as Muslim will of course obey each provision which is stated on the 
holy Qur'an and hadith. The influence of Islam toward the culture or patriarch is quite massive because it is related to the Islamic concepts and regarding to the most of Malay people are Muslim. The number and the percentage of the people according the group of ethnics shows that the Malay is in the rank 10 of the most populous ethnic with 5.365 .399 of people or $2.27 \%$ of all Indonesian people. The number of Muslim in Indonesia in 2010 is 207.2 million of people $(87.18 \%)$, he the Christian is 16.5 million people $(6.96 \%)$. While the Malay people in Indonesia are various such as Malay Asahan, Malay Deli, Malay Riau, Malay Langkat, Malay Banyu Asin, Malays Asahan, Malay Lahat, Malay Semendo (Na'im \& Syaputra, 2011). The Melay people mostly are Muslim while the spread is on the Sumatera. The patriarchal culture is quite influential to the people of Malay where the male is considered as a strong person, a leader in housewifery, and the main source of family income. Like with the teachings of the Islamic religion and what Almighty Allah explains that male is the leader. Allah says:

\begin{abstract}
"Men are in charge of women by [right of] what Allah has given one over the other and what they spend [for maintenance] on their wealth. So righteous women are devoutly obedient, guarding against [the husband's] absence what Allah would have them guard. But those [wives] from whom you fear arrogance - [first] advises them; [then if they persist], forsake them in bed; and [finally], strike them. But if they obey you [once more], seek no means against them. Indeed, Allah is ever Exalted and Grand." (An-Nisâ' [4]: 34).
\end{abstract}

It is clear that in the Holy Quran through An-Nisâ' [4]: 34 that male is the leader of the female. In Islam, female should obey the husband as the leader of the family both when they are in the distance and not. As a leader, sometimes, male forgets to be a leader must make righteous decisions and not arbitrary which violates the Islamic Sharia.

As a nation with strong patriarchal culture system, the position of male is dominating against female where the female is always considered weak so that they are always being in the number two. From that position, the division of work duty for male and female exists. This division exists because the male is the one that makes the decision both in the scope of family and public. The patriarchal culture delimited the opportunity for female in the public space. It is depicted in the political condition in Indonesia where the participation of male and female are in inverse comparison (Nimrah \& Sakaria, 2015). With such difference, there will be imbalance in the process of decision making. The decided decision will tend to be gender sensitive. Basically, the female's participation in the growth of politic is crucial, because the development should involve gender which is male and female so that the development which is gender sensitive may prevent the made of unilateral decision which causes injustice for Indonesian females. What is to be considered in this case is that it is not only male who is involved but the female as well. This awareness should be grown to minimalize gender injustice (Randi, 2016). If it is related to Islamic concept, gender justice in this case does not mean simple the male level is higher than the female's.

\begin{abstract}
"O mankind, fear your Lord, who created you from one soul and created from it its mate and dispersed from both of them many men and women. And fear Allah, through whom you ask one another, and the wombs. Indeed Allah is ever, over you, an Observer." (An-Nisâ’ [4]: 1).
\end{abstract}

With the patriarchal culture, males have crucial role in giving decision, until sometimes the decision is so not balance like what is urged by (Atem \& Nusantara, 2016) entitled "Women Existence as the Primary Factor of Food Security (A Case Study: Female Malay Farmers in Samayong Village, District of Sambas, East Kalimantan)" where human has fundamental rule in the food security especially in the process of sowing seeds, planting, nurturing, harvesting, and falling out rice. While the male works in the other fields. This kind of work division is influenced by the male's role as the head of a family where the system has existed on years. Then, the research by (Nimrah \& Sakaria, 2015) with the title of "Women and Patriarchal Culture in Politic (A Case Study of Female Legislative Candidates Failure in Legislative Elections)" resulted that a lot of women take part in politics, but the obstacles to overcome are massive which is the patriarchal culture where the male's domination in each decision. Besides, the low role of female legislative members is caused the strong patriarchal culture. Regarding to that case, the researcher is interested to conduct a research on how is the influence of Islam in the patriarchal culture in the Malay people, considering that there is no such research so far.

\section{Materials and Methods}

\subsection{Methods}

The research employs qualitative approach. The reason for picking qualitative approach is that to discover how the role of Islam is toward the patriarchal culture among Malay people. The research object is the Malay people in Sumatra. The data source applied to this study is secondary data. While the secondary data is in form of documents, archive, letters, and books which is directly related to the construction. The library study is conducted for two months from December $1^{\text {st }}$ to January $25^{\text {th }}, 2017$ where the information is retrieved from reading source from several 
category: public reference sources, textbooks, articles, e-journal, and research result. The data collection technique employs literature study.

\subsection{Result and Discussion}

The relationship between women and men in the Muslim community are generally influenced by the patriarchal system, in understanding the religion and culture, so that the culture will shape the culture of patriarchy that think men is stronger than women, even though Islam is the religion of the anti-patriarchy, that upholds justice and respect for human beings rather than on the basis of sex, but rather his efforts (Nurmalia, 2015). Based on the historiography of local-traditional, there are several points which can be inferred in the proses of Islamization (PaEni, 2009). First, Islam in Indonesia was initially brought from the Arabian land. Second, Islam was introduced by the teachers or preachers. Third, the first people to be converted to Islam were those who have power. Fourth, most of the preachers came to Indonesia in the $12^{\text {th }}$ and $13^{\text {th }}$ century A.D. Then, the national diversity of Indonesia came true where the visible diversity is not only the numerous tribes in Indonesia, but also the varying religions embraced by Indonesian people. The harmonic atmosphere of religious life among the heterogeneous society with various religious background are the reality because of the people's tolerance which respects the difference. Numerous socio-cultural activities in a society like gotong royong or mutual cooperation is conducted together by the whole member of the society regardless the group of society, tribes, and religions (Na'im \& Syaputra, 2011). All difference and distinctive of each human then persuade them to know each other and develop mutual respect and appreciation among them (Azra, 2006). The diversity is inseparable from several religions taught about good deeds toward human like what is explained in the words of Allah:
"And for everyone to some degree because of what they do. Your God will not forget what they did." (Al-An'aam [6]: 132)

From the verse above, any action will find retaliation for the afterlife whether it is good or bad. To analyze how Malay people hold strong the patriarchal system, where the influence of Islam towards the patriarchal culture, the required data is how the condition and the reality Muslim Malay people especially Malay people in Sumatra. Indonesia is an archipelago with the fourth most populous country in the world. To be able to analyze how is the influence of Islam in the patriarchal culture of course can be examined from the number of Muslim in Indonesia, then the number of Muslim in each region. Indonesia has the most Muslim population which is spread in various regions of Indonesia.

Table 1. The Quantity and Percentage of Resident according to The Embraced Religion in 2010

\begin{tabular}{|c|c|c|}
\hline Religion & Quantity (people) & Percentage (\%) \\
\hline$(1)$ & $(2)$ & $(3)$ \\
\hline Islam & 207.176 .162 & 87.18 \\
\hline Kristen & 16.528 .513 & 6.96 \\
\hline Katolik & 6.907 .873 & 2.91 \\
\hline Hindu & 4.012 .116 & 1.96 \\
\hline Budha & 1.703 .254 & 0.72 \\
\hline Khong hu cu & 117.091 & 0.05 \\
\hline Others & 299.617 & 0,13 \\
\hline Not answer & 139.582 & 0.06 \\
\hline Not ask & 757.118 & 0.32 \\
\hline Jumlah & 237.641 .326 & $100 \%$ \\
\hline
\end{tabular}

Source: BPS, 2010 (Na'im \& Syaputra, 2011)

Based on the table above, the number of Muslim holds the highest number of Indonesian population of the number of $87.18 \%$ of 207.176 .162 Muslims, while the least population embraced Khong $\mathrm{Hu} \mathrm{Cu}$ in the number of $0.05 \%$ of 117.091 people. From the data, it is clear that Islam is a dominant religion embraced by most of the Indonesian.

Table 2. The Malay People and Muslim in Indonesia

\begin{tabular}{|c|c|c|c|}
\hline No. & Category & \multicolumn{2}{|c|}{ Number } \\
\hline I & Number of Malay People & \multicolumn{2}{|c|}{5.365 .399} \\
\hline \multirow[b]{2}{*}{ II } & \multirow[b]{2}{*}{ Number of Malay People according to the sex } & Male & Female \\
\hline & & $2.696036(50.05 \%)$ & $\begin{array}{l}2.669 .363 \\
(49.45 \%) \\
\end{array}$ \\
\hline \multirow{2}{*}{ III } & \multirow{2}{*}{$\begin{array}{l}\text { Number of Malay People according to the } \\
\text { location of residence }\end{array}$} & Urban Area & Rural Area \\
\hline & & $(45.31 \%)$ & $(54.69 \%)$ \\
\hline IV & $\begin{array}{c}\text { Number of Malay People in The Province of } \\
\text { South Sumatra }\end{array}$ & \multicolumn{2}{|c|}{602.741 people } \\
\hline $\mathrm{V}$ & $\begin{array}{c}\text { Number of Muslim resident in South Sumatra } \\
\text { Province }\end{array}$ & \multicolumn{2}{|c|}{ 7.218.951 or Muslim $96.89 \%$} \\
\hline \multirow[b]{2}{*}{ VI } & \multirow{2}{*}{$\begin{array}{c}\text { Number and percentage of Muslim resident } \\
\text { acoording to the sex in South Sumatra } \\
\text { Province }\end{array}$} & Male & Female \\
\hline & & $104.195 .783(50.29 \%)$ & $102.980 .379(49.71 \%)$ \\
\hline \multirow{2}{*}{ VII } & \multirow{2}{*}{$\begin{array}{l}\text { Number and percentage of Muslim resident } \\
\text { acoording to the location of resident }\end{array}$} & Urban Area & Rural Area \\
\hline & & $104.528 .568(50.45 \%)$ & $102.647 .594(49.55 \%)$ \\
\hline
\end{tabular}


Based on the data onto, it shows that the number of Malay people in Indonesia is 5.365.399 which is separated from several provinces in Indonesia. Then, the number of Malay people in rural area is more populous than the urban area, so it is quite to make sense that the traditional value remains valid in the rural area. The number of Malay people in South Sumatra is many. Most of the people of South Sumatra are Muslim in the percentage of $96.89 \%$. The number of male Muslim is bigger than the female Muslim in the number of 104.195 .783 people. The number of Muslim in rural area is smaller in the number of 102.647 .594 or $49.55 \%$ than the number of Muslim in urban area which is in the number of 104.528 .568 or $50.45 \%$. Data is retrieved from the census in 2010 (SP2010), besides the dynamics of social structure in the society can be examined in a study using SP2000 (Na'im \& Syaputra, 2011). Muslim in rural area has stronger patriarchal culture than the Muslim in urban area. The people living in rural area hold the cultural value stronger so the people obey the rule made in the society or the religion. For the Malay people, the level of obedience is stronger. In Islam, obeying husband is a must and an observance. The level of worshiping obedience determines whether or not somebody's feeling is soft. The higher the obedience, the more sensitive the feeling in interacting with being contaminated the environment (Sapuri, 2009). Like what happens to the Malay people of West Kalimantan where the female works on farm while the male works on the other fields.

But the patriarchal culture is not a culture that is considered good, because in a patriarchal culture women always suffered discriminatory. In contrast to the concept in Islam that men acted to protect women not discriminatory, because Islam believes that every bad deed will get a reward, i.e., the torment of hell. Discriminatory patriarchal culture and behavior in society as real have been considered weak women almost in all the Affairs of life (Guamarawati, 2009). Error in interpret male is the leader in the household, will lead to discriminatory itself. As with any community Indonesia that tend to be females in domestic, up to no good policy rarely every family present, the public always have social inequality. The women become victims. So in the system of patrilineal people, made possible the existence of patriarchal culture, namely when adult women have the most privileged position in decision-making and the control of assets of the family (Nurmalia, 2015).

Patriarchal culture developed around the world, is no exception of Malay and Javanese. Where men are considered to have a much stronger physically than women, women biologically are considered weaker. Where it has been going on Division of labor based on gender. Men are considered able to keep families from outside attack or crime against his family. This Division of labor led to the development of social roles is limited to both sexes, and the creation of a power difference in some respects more profitable men (Hermawati, 2007) and detrimental to women. But in its own Muslim men have to trial on women.

If a woman feareth ill treatment from her husband, or desertion, it is no sin for them twain if they make terms of peace between themselves. Peace is better. But greed hath been made present in the minds (of men). If ye do good and keep from evil, lo! Allah is ever informed of what ye do (Al-Qur'an surah al-Nisa '44]: 128).

Rahayu (2011) cited by (Putri, 2015) citing that the pattern of Division of labor within the family contributes a few things, namely; 1) Government policy contained in various regulations, where the policy is not a patriarchal ideology and gender fairness in the legal system in Indonesia, is still very strong. 2) factor in education, education in Indonesia requires the male to become a leader in class or small groups that were created. 3) values tradition, values tradition became one of the factor pattern Division of labor within the family, in the traditional female values have restrictions against access to education, and is in the shutter public, such as women who are well known in Indonesia as the emancipation of women Mother R. A. Kartini, who do not have opportunities to educated at that time. 4) patriarchal culture in particular cultures, patriarchal cultures consider men was the leader in the family but did not join with responsibility and love. 5) mass media, women are used as a tool to earn profit through social media. 6) environment namely the views of the community were ambiguous. In addition, the author also did an analysis of the role of Islam against the patriarchal culture in Malay society, find some basic results proved important and interesting enough by the author, IE: based on paragraph (QS. An-Nisâ ' [4]: 34) "Men are in charge of women... "that the position of men is higher compared to women in terms of lead. In the Islamic history only a few names of the women who appear in history as Âminah, the mother of the Apostle of ALLAH., Khâdijah, wife of Apostle, Fâthimah, daughter of Âisyah, the wife of the Messenger, Messenger, Âisyah, brothers ' Asmâ, and Rabi'ah al-sufi, Adawiyah women. Moreover, the history of ha whom about participation of male domination of the da-lam patriarchal culture, besides communities also were more likely to give Indonesia a place and public speaking opportunities such as lectures in mosques, in the sermon of marriage or in other events to males because male assumption is certainly more could be from women (Nurmalia, 2015).

According to Clifford Geertz (1973:89) in (Heriyanto H. , 2011), culture is a symbolic system of significance which is the patterns of meaning which embodied in the symbols which are inherited historically as human communicated, preserve and develop science and attitude toward life. The patriarchal culture has role in the social life of the society. With the existence of the patriarchal culture, the work division into male and female happens. 
The work division of Malay people has existed on generations. In encountering dominations of patriarchal cultural values and discriminative situation, the female's agenda in politics should be initiated by awareness rising programs, especially shifting the mindset and perspective of the entire society (male and female) about the principles of democracy which guarantees the equality, human rights, law and justice supremacy (Musdah, 2007). According to Hegel (1956) for the universal unity truth is subjective and will; and universal is to be found in the country, his laws of universal and rational order. The country is the idea of the divine, as in there is on this earth (Turner, 2003).The patriarchal culture is considered negative for the most of people because the patriarchal culture indicates the dominance of male against the female where sometimes the domination is like the rights of the male. Even more, the male often misused the domination against the female so violence is quite frequent to happen.

Patriarchal culture is a set of system of ideas which is made by the society where the male's dominance is stronger against the female. The system is deeply rooted, inherited through generations and existing in various areas in Indonesia. One of Indonesian societies whose hold patriarchal culture strongly is the Javanese. From the monarchy system, they think that woman should be protected, secluded, and given no opportunity to have education. This condition pushes the female deeper to the corner. So, years to years, the female got pushed deeper to the corner and the developments reach the imbalance. Female is forced to be faced to the injustice problem where female feels that they are marginalized and considered be able to move in domestic space as well as almost no time to move in public space (Randi, 2016). While according to Koentjaraningrat (1985) in (Heriyanto, 2011), three areas of cultural structure of super-system are ideofact system which exists on the deepest circle of the area.

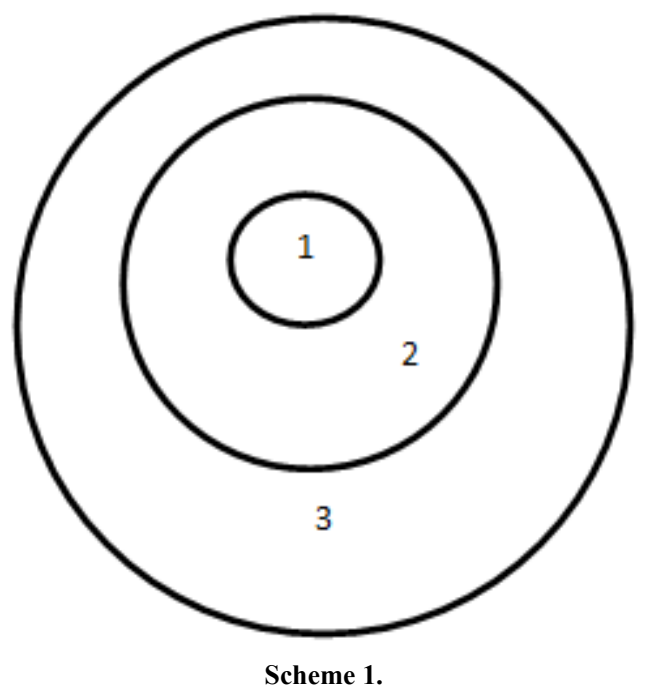

From the super-system, the ideofact can be explained that it is in the most inner place. Then, sociofact is in the level of second circle and artefact win form of material is in the third circle. Without the background of cultural awareness and the perspective of Islam which is sturdy as the ideofact (system of ideas), any Islamization program will find the dead end (Heriyanto, 2011). The patriarchal culture is ideas cultural system which exists in Islam where the values are implanted in early ages in a family and children education. The patriarchal culture grows in the traditional society or the people of rural area where the obedience attitude toward the male is a form of service of dedication to the husband.

Idea or thoughts of obedience becomes a tradition system to obey. While the characteristics of traditional Islam is following (Nata, 2001): exclusive (limited access), traditional Islam refuses thoughts, opinions, and suggestions from the outside especially from the field of spiritual, fails to distinguish things belong to the religious teaching and do not. For example, covering body, is in form of something to wear in various shapes and it is not the teaching; backwardly orientation, that the law decision in the past is an ideal example to follow; tends to be textualist-literalist, understanding the verses in the Holy Quran textually without considering the background and social situation which may cause the verse to reveal; tends to less appreciating time, traditional Islam often does something without estimating the required time to spend; does not take the tradition in the religion; puts feeling first before critical thinking; tends to be explanatory and theoretical which is the attitude of submissive, subservient, and obedient toward the Almighty God accompanied with the belief that everything is possible as long as God permits it; less appreciating the modern science and technology; jumud and stat are unwillingness to follow a change but keep on what is considered as good from the past without questioning it critically whether what they believe is still strong enough to compete with the other power. By those characteristics of traditional Islam, the conclusion is that many of Indonesian society especially the rural area residents embrace the traditional Islam. While, traditional Islam in Indonesia (Nata, 2001) is where worshipping is quite strong including the sunnah ones. They are so obedience, diligent, and earnestly conducting the worshipping like sholat, dzikir, etc. Besides, they are also wear distinctive garments which they think what is worn by Rasulullah Muhammad SAW, such as wearing turban as the headgear or udeng, carrying tasbih, growing beard, eating by using the right hand, often be in mosques. The other dimension is sociology where they tend to live in groups and do not belong to the other group. Another dimension is the understanding which is literal, so what they consider as sunnah they do it consequently.

\section{Conclusions}

Patriarchal culture in Malay people is more or less 
influenced by Islam especially the society of traditional Islam in Indonesia. The society of traditional Islam in Indonesia has higher obedience toward worshipping and the religious orders. Patriarchal culture in Islam is the shape of system of ideas and values which are considered as good because under the patriarchal culture, the women are protected. Unfortunately, sometimes, patriarchal culture is far beyond Islamic teaching where violations against women seldom take place.

Patriarchal culture emphasises on the heritage line of male or father-ship, not the wrong cultural system as long as it does not lead to gender injustice. The patriarchal culture finds may mistakes in the realty. Patriarchy puts male as primary where they are responsible to make decision or deciding rights, so with the rights, the male is khalaf or forgetting that female should be protected.

\section{Acknowledgements}

This research was supported by Indonesia Endowment Fund for Education (LPDP) as one of the funding agencies and credible scholarship and has the values of honesty, integrity, responsibility.

\section{REFERENCES}

[1] Atem, \& Nusantara, A. S. (2016). Eksistensi Perempuan Sebagai Penggerak Utama Ketahanan Pangan (Studi Kasus:Petani Melayu Perempuan di Dusun Semayong, Kabupaten Sambas, Kalimantan Barat). Politik dan Kebudayaan (pp. hlm.9, ISBN 978602630889). Bandung: UNPAD Press.

[2] Azra, A. (2006). Pluralitas dalam Masyarakat Islam . Jakarta: MataAir Publishing.

[3] Guamarawati, N. A. (2009). Suatu Kajian Kriminologis mengenai kekerasan terhadap Perempuan dalam Relasi
Pacaran Heteroseksual. JUrnal Kriminologi Indonesia, Vol.5 No. 1, 43-55.

[4] Heriyanto, H. (2011). Menggali Nalar Saintifik Peradaban Islam. Bandung: Mizan Publika.

[5] Hermawati, T. (2007). Budaya Jawa dan Kesetaraan Gender. Jurnal Komunikasi Massa, Vol. 1, No.1 , 18-24.

[6] Musdah, M. S. (2007). Menuju Kemandirian Politik Perempuaan (Upaya Mengakhiri Depolitisasi Perempuan di Indonesia). Yogyakarta: Kibar Press.

[7] Na'im, A., \& Syaputra, H. (2011). Kewarganegaraan, Suku Bangsa, Agama dan Bahasa Sehari-hari Penduduk Indonesia. Jakarta: Badan Pusat Statistik.

[8] Nata, A. (2001). Peta Keberagaman Pemikiran Ilsam di Indonesia. Jakarta: PT RajaGrafindo Persada.

[9] Nimrah, S., \& Sakaria. (2015). Perempuan Dan Budaya Patriarki Dalam Politik (Studi Kasus Kegagalan Caleg Perempuan Dalam Pemilu Legislative 2014 ). The Politics: Jurnal Magister Ilmu Politik Universitas Hasanuddin, Vol. 1, No. 2.

[10] Nurmalia, N. (2015). Pengaruh Budaya Patriarki Terhadap Pemahaman Agama Dan Pembentukan Budaya . KARSA, Vol. 23 No. 1,

[11] PaEni, M. (2009). Sejarah Kebudayaan Indonesia. Jakarta: PT RajaGrafindo Persada.

[12] Putri, D. P. (2015). Pembagian Peran Dalam Rumah Tangga pada Pasangan Suami Istri Jawa. Jurnal Penelitian HUmaniora, Vol.16, No.1, 72-85, ISSN: 1411-5190.

[13] Randi. (2016). Partisipasi Perempuan dalam Bidang Politik vs Budaya Masyarakat Indonesia. Politik dan Kebudayaan (pp. hlmn. 50, ISBN 978602630889). Bandung: UNPAD Press.

[14] Rasjid, S. (2007). Fiqih Islam. Bandung: Sinar Baru Algesindo .

[15] Sapuri, R. (2009). Psikologi Islam. Jakarta: PT RajaGrafindo Persada.

[16] Turner S. Bryan. (2003). Relasi Agama dan Teori Sosial Kontempore. Yogyakarta: IRCiSoD 